\title{
Assessing Nurses' Knowledge and Performance Regarding Shift Report Handover
}

\author{
Sanaa Ramadan Abdel-Aal ${ }^{1}$, Fatma Rushdy Mohamed ${ }^{2}$ \& Soad Ahmed Ghallab ${ }^{3}$. \\ ${ }^{1 .}$ Head Nurse at Cardiac and Digestive System Center, Sohag City, MDS, Nursing Administration, Egypt. \\ 2. Professor of Nursing Administration, Faculty of Nursing, Assiut University, Egypt. \\ ${ }^{3 .}$ Assist. Professor of Nursing Administration, Faculty of Nursing, Assiut University, Egypt.
}

\begin{abstract}
Background: Handover facilitate the safe transfer of patient information in organization, the transfer of patient information into a logical format to reduce the omission of important information and to facilitate consistency in the process. Aim to assess nurses' knowledge and performance regarding shift report handover. Study design: A descriptive design was used to carry out the study. Setting: This study was conducted in the Cardiac and Digestive System Center at Sohag City which affiliated to Ministry of Health (MOH). Subject: The study included (45) staff nurses. Tools: Two tools of data collection were used namely; first tool knowledge questionnaire which divided into two parts: part 1 included questions about personal characteristics of the staff nurses, part 2 consisted of multiple choice questions; and second tool an observational checklist. Results: The main study results illustrated that majority of studied nurses had very deficient total knowledge regarding shift report handover and low of performance regarding shift report handover. Conclusion: the staff nurses in the study setting have deficient knowledge and inadequate performance of communication and shift report handover. There were significant positive correlation between knowledge score and performance score. Recommendations: Hospital decision makers should create strategies to manage the quality of shift handover. The applicability of shift report handover should be supported from the hospitals administration.
\end{abstract}

\section{Keywords: Communication, Documentation, Knowledge, Nurses, Performance \& Shift Handover.}

\section{Introduction}

Good communication between nurses and patients is essential for the successful outcome of individualized nursing care of each patient. Communication is a vital element in nursing in all areas of activity and in all its interventions such as prevention, treatment, therapy, rehabilitation, education and health promotion, communication is a dynamic, continuous, and multidimensional process for sharing information as determined by standards or policies. Reporting and recording are the major communication techniques used by health care providers to direct patient-based decisionmaking and continuity of care (Barbara, \& Lynne, 2018).

Communication can be defined as the process of exchange information, thoughts and feelings among people using speech or other means. The therapeutic practice involves the oral communication of public health officials and nurses on the one hand. It is a two way process. The patient conveys their fears and concerns to their nurses and helps them make a correct nursing diagnosis. The nurse takes the information and in turn transmits other information to the patient with discretion and delicacy as to the nature of the disease and advises with treatment and a rehabilitation plan for health promotion. Also the process of exchanging information and transmitting meanings between two or more individuals (Wikstrom, \& Svidén, 2014).
Nursing documentation is believed as important indexes to develop nursing care. Documentation encompasses all written and/or electronic entries reflecting all aspects of patient care communicated, planned recommended or given to that patient. Also, documentation is any communicable material that is used to describe, explain or instruct regarding some attributes of an object, system or procedure, such as its parts, assembly, installation, maintenance and use (Collins, et al., 2018).

Nursing documentation is a vital component of safe, ethical and effective nursing practice, regardless of the context of practice or whether the documentation is paper-based or electronic. This document describes nurses' accountability and the expectations for documentation in all practice settings, regardless of the documentation method or storage. Nursing documentation is essential for good clinical communication. Documentation is a nursing action that produces a written and/or electronic account of pertinent client data, nursing clinical decisions and interventions, and the client's responses in a health record (Potter, et al., 2017).

Report is essential for nursing practices and it is an attempt to reflect the nursing process and to underpin the decision-making process. Systematic and purposeful documentation itself produces evidence. Thus, as a result of nursing care documentation, valid and reliable evidence is produced on a daily basis. 
The patient report is naturally a vital parameter in health care. The report is used as a basis for care delivery, for communication between practitioners and institutions as a document to ensure continuity of care. Documentation of nursing care is a very important aspect of every nurse's job as the old saying goes "if it is not documented it is not done" (Kelley, et al., 2014).

Handing over patient care at the end of shift is an intricate part of nursing care, which requires nurses to use effective communication to transfer patient information from an off-going nurse to the on-coming nurse. The quality of nursing care a patient receives during a shift, to an extent, is usually dependent on the effectiveness of communication between nurses (Winifred, 2017). Handover, or transition in care, is known to be a danger point in the patient care process for a long time. Ineffective communication during handover is one of the most common identified cause of catastrophic or sentinel events in hospitals (The Joint Commission on Accreditation of Health Organization, [JCAHO], 2016).

The concept of patient hand over is one that has come into sharper focus over the last decade. Agency for Healthcare Research and Quality, (AHRQ, 2012) identified that the term "hand off" is often used interchangeably with other terms such as handover signout, sign over, cross coverage, and shift report. A hand over is the transfer of information and responsibility for the care of a patient from one healthcare provider to another. Hand offs occur frequently and at various stages throughout the patient's stay.

\section{Significance of the study}

Communication failures in healthcare are linked to adverse patient outcomes (Anderson et al., 2015). Since 2012, The Joint Commission on Accreditation of Health Organization has estimated that $80 \%$ of sentinel events are related to communication failures.

During the nursing supervisor's hospital round, an incident was observed between two nursing personnel in the CCU. The nurses were disputing the results of blood tests taken earlier which showed the results for "cardiac enzymes" and not the required test which was for "blood result". The incident occurred as a result of miscommunication between nurses and illegible doctors' comments. The incident resulted in the patient having to undergo further repeated blood tests as well as additional costs to both the patient and the hospital. The incident didn't go with quality hospital and patient safety standards.

\section{Aim of Study}

Assess nurses' knowledge and performance regarding the shift report handover.

\section{Research questions}

1. What is the nurses' knowledge regarding shift report handover?
2. What is the nurses' performance regarding shift report handover?

3. What are the relationship between nurses' personal data and their nurses' knowledge and performance regarding shift report handover?

\section{Subject \& Method}

The study was portrayed according to the four following designs

1. Technical design.

2. Administrative design.

3. Operational design.

4. Statistical design.

Technical design

This design was involved the study design, setting, subject, and data collection tools.

Research design

A descriptive design was used to carry out the study. Setting

This study was conducted in the Cardiac and Digestive System Center at Sohag City which affiliated to Ministry of Health (MOH). The bed capacity of this center is 108 beds.

Subject

The subjects of this study included all staff nurses who assigned to work in aforementioned settings during the data collection period with total number (45) nurses.

\section{Tools of data collection}

The tools of this study included the following:

A self- administered questionnaire consisted of two main parts

Part (1): This part aimed to collecting data related to the personal characteristics included staff nurses. It covered items as age, gender, marital status, educational qualification, years of experience, and attended training programs.

Part (2): knowledge shift report handover questionnaire sheet which adopted from Abdel-Aal, (2016). It consisted of twenty six closed ended questions regarding shift report handover, and multiple choice questions categorized into two main dimensions: Communication (11) items and Shift report handover (15) items.

\section{Scoring system:}

For each knowledge question, a score "1" was given for a correct answer and "0" for the incorrect one..

\section{Observational checklist}

An observation checklist adopted from Abdel-Aal, (2016). In order to collect data related to the actual performance of nurses during the shift report handover procedure. This tool was consisted of (43) items. These items were divided into three main dimensions. First dimension preparation of pre-report hand-over consists of 5 items (writing shift's report, ensuring that the information for each patient is complete, ect), second dimension criteria of handover process consists of 10 items (conduct oral shift report at time, exchange the 
contents of report at patient's bed, Face to face interaction, ect ) and third dimension Exchange contents of shift report includes: A - Patient's information 5 items(Patient full name, Patient's age, ect), B- Patients health status 3 items(Date of admission, Patients diagnosis, ect),C- Procedures done to the patients 13 items (Patient's vital sings, Patient medication intake, patient's level of awareness, ect) and D- New physician instructions 7 items(new medication instructions, changes in the diet, ect).

\section{Scoring system}

The results of observation checklist categorized either "done" or "not done". These were respectively scored 1 and zero.

\section{Administrative Design}

Official permissions to conduct the study were obtained from pertinent authorities. The researcher met with the Cardiac and Digestive System Center director and explained to him the purpose of the study and the methods of data collection to obtain their permission to conduct the study.

\section{Ethical considerations}

The study protocol was approved by Ethical Committee of the Faculty of Nursing, Assuit University. The aim of the study was explained to officials as well as to all study participants. The participants were reassured that any obtained information would be confidential, and used only for the purpose of research. The study maneuvers had no actual or potential harms on participants. The study beneficence was clear in the improvement of performance of nurses, which would be reflected positively on their settings.

\section{Operational design \\ Preparatory phase}

The researcher review of current and past local and international related literature and theatrical knowledge of various aspects of the study using books, articles magazines and internet to be acquainted with study subject.

\section{Pilot study}

Pilot study was conducted to assess clarity, accessibility and feasibility of the questionnaires and to detect the obstacles and problems that may be encountered during data collection. It was done on four staff nurses representing 10\% (4 nurses) who are included in the total study sample. Knowledge questionnaire was distributed to them and time consumed was calculated for filling the questionnaire, it was ranged from 20 - 30 minutes. The time consumed to complete observation checklist sheet was 20-25 minutes.

\section{Tool validity \& Reliability}

Cronbach alpha coefficient was calculated to assess the reliability of the knowledge questionnaire with total $(\alpha$ $=0.78$ ) , and for observational checklist the highest reliability coefficient was $100 \%$ and the lowest reliability coefficient was $33 \%$, as the mean of reliability coefficient was $88 \%$ which is confirming the stability of the questionnaire.

Face and content validity of the tools was assessed by jury group consisted of 5 experts in nursing administration. The jury members were professors and assistant professors from Faculty of Nursing, Assuit University. The tools were distributed to a jury group to judge its' comprehensiveness, accuracy and clarity.

\section{Field work}

The researcher collected data through meeting each staff nurse individually in the working unit, explaining the aim of the study and the method of filling out the questionnaire. Knowledge questionnaire was distributed to nurses after the end of morning and night shift at their working place. The researcher giving each nurse her copy to fill it and handed it back to the researcher at the same time after answering all questions. the answer of questions was taken within 20 - 30 min for each nurse. The number of staff nurses who participated were ranged from 3 to 4 participants two days every week.

The researcher observed the actual performance of nurses during shift report handover by herself. The observation was done during morning and night shifts. The observation was taken within 20-25 min for each nurse. The researcher observed from 2 to 3 nurses every day two times weakly. The whole duration for data collection took about two months from April 2019 to May 2019.

\section{Statistical Design}

Collected data were verified prior to computerized data entry analysis by using Statistical Software Package for Social Sciences (DPSS) version 20 program. Data were presented using descriptive statistical in the form of percentages also mean and standard deviations were calculated. For relation between variables (chi - square) was used statistical significant was considered at pvalue $\leq \mathbf{0 . 0 5}$. 


\section{Results}

Table (1): Percentage distribution of personal characteristics of the studied staff nurses ( $n=45)$.

\begin{tabular}{|c|c|c|}
\hline personal characteristics & No. (45) & $\%$ \\
\hline \multicolumn{3}{|l|}{ Age:(years) } \\
\hline$<25$ & 34 & 75.6 \\
\hline$\geq 25$ & 11 & 24.4 \\
\hline Mean \pm SD (Range) & \multicolumn{2}{|c|}{$23.98 \pm 2.22(21.0-32.0)$} \\
\hline \multicolumn{3}{|l|}{ Gender: } \\
\hline Male & 5 & 11.1 \\
\hline Female & 40 & 88.9 \\
\hline \multicolumn{3}{|l|}{ Educational qualification: } \\
\hline Bachelor of Nursing science & 6 & 13.3 \\
\hline Technical Health Institute ( Nursing branch) & 39 & 86.7 \\
\hline \multicolumn{3}{|l|}{ Years of experience: } \\
\hline $1-2$ & 32 & 71.1 \\
\hline 3 or more & 13 & 28.9 \\
\hline Mean \pm SD (Range) & \multicolumn{2}{|c|}{$2.49 \pm 1.58(1.0-7.0)$} \\
\hline \multicolumn{3}{|l|}{ Marital status: } \\
\hline Single & 31 & 68.9 \\
\hline Married & 14 & 31.1 \\
\hline \multicolumn{3}{|l|}{ Attending training courses: } \\
\hline Yes & 6 & 13.3 \\
\hline No & 39 & 86.7 \\
\hline
\end{tabular}

Table (2): Percentage distribution of nurses' knowledge regarding shift report handover $(n=45)$.

\begin{tabular}{|l|c|c|c|c|}
\hline \multirow{2}{*}{\multicolumn{1}{|c|}{ Items }} & \multicolumn{3}{c|}{} \\
\cline { 2 - 5 } & \multicolumn{2}{c|}{ Correct } & \multicolumn{2}{c|}{ Incorrect } \\
\cline { 2 - 5 } & No. & $\mathbf{\%}$ & No. & \% \\
\hline Types of nursing report about patients care in the department & 5 & 11.1 & 40 & 88.9 \\
\hline The shift's report is a tool & 10 & 22.2 & 35 & 77.8 \\
\hline Definition of report & 6 & 13.3 & 39 & 86.7 \\
\hline The criteria for good report & 13 & 28.9 & 32 & 71.1 \\
\hline The Goal of the Shift handover & 10 & 22.2 & 35 & 77.8 \\
\hline The introductory information of shift handover & 12 & 26.7 & 33 & 73.3 \\
\hline The information about shift handover elements & 9 & 20.0 & 36 & 80.0 \\
\hline The content of shift's handover & 11 & 24.4 & 34 & 75.6 \\
\hline The person who write shift's handover & 4 & 8.9 & 41 & 91.1 \\
\hline The place of writing shift's handover & 12 & 26.7 & 33 & 73.3 \\
\hline Time of shift handover affairs & 10 & 22.2 & 35 & 77.8 \\
\hline The criteria required for the place of exchanging the shift handover & 12 & 26.7 & 33 & 73.3 \\
\hline $\begin{array}{l}\text { The person in charge of communicating the shift's handover to the } \\
\text { next shift }\end{array}$ & 6 & 13.3 & 39 & 86.7 \\
\hline The Persons who involved in shift handover exchange & 7 & 15.6 & 38 & 84.4 \\
\hline The procedures established during the shift hand over & 5 & 11.1 & 40 & 88.9 \\
\hline
\end{tabular}

Table (3): Total mean score of staff nurses' knowledge regarding shift report handover $(n=45)$.

\begin{tabular}{|l|c|}
\hline \multicolumn{1}{|c|}{ Items } & Mean \pm SD \\
\hline Knowledge about communication & $2.09 \pm 2.32$ \\
\hline Knowledge about reporting & $2.93 \pm 1.74$ \\
\hline Total score of knowledge & $\mathbf{5 . 0 2} \pm \mathbf{3 . 7 6}$ \\
\hline
\end{tabular}


Table (4): Total mean score of staff nurses performance regarding shift report handover $(n=45)$.

\begin{tabular}{|c|c|}
\hline Items & Mean \pm SD \\
\hline Pre-report hand-over preparation & $1.04 \pm 1.35$ \\
\hline Criteria of handover process & $2.87 \pm 1.58$ \\
\hline Exchange contents of shift report & $6.00 \pm 5.79$ \\
\hline a. Patient's information & $0.84 \pm 1.13$ \\
\hline b. Patients health status & $0.71 \pm 0.87$ \\
\hline c. Procedures done to the patients & $2.87 \pm 2.94$ \\
\hline d. New physician instructions & $1.58 \pm 2.04$ \\
\hline Total score of performance & $9.91 \pm 7.94$ \\
\hline
\end{tabular}

Table (5): Relationship between nurses' knowledge score regarding shift report handover and personal characteristics.

\begin{tabular}{|c|c|}
\hline \multirow{2}{*}{ personal characteristics } & \multirow{2}{*}{$\begin{array}{c}\text { Knowledge score } \\
\text { Mean } \pm \text { SD }\end{array}$} \\
\hline & \\
\hline \multicolumn{2}{|l|}{ Age: (years) } \\
\hline$<25$ & $4.03 \pm 2.88$ \\
\hline$\geq 25$ & $8.09 \pm 4.59$ \\
\hline P-value & $0.001 *$ \\
\hline \multicolumn{2}{|l|}{ Gender: } \\
\hline Male & $3.80 \pm 2.77$ \\
\hline Female & $5.18 \pm 3.86$ \\
\hline P-value & 0.447 \\
\hline \multicolumn{2}{|l|}{ Educational qualification } \\
\hline Bachelor of Nursing & $10.00 \pm 3.10$ \\
\hline Technical Health Institute & $4.26 \pm 3.25$ \\
\hline$P$-value & $0.000 *$ \\
\hline \multicolumn{2}{|l|}{ Years of experience } \\
\hline $1-2$ & $4.03 \pm 3.02$ \\
\hline 3 or more & $7.46 \pm 4.37$ \\
\hline P-value & $0.004 *$ \\
\hline \multicolumn{2}{|l|}{ Marital status } \\
\hline Single & $5.32 \pm 3.52$ \\
\hline Married & $4.36 \pm 4.31$ \\
\hline P-value & 0.431 \\
\hline \multicolumn{2}{|l|}{ Attending training courses } \\
\hline Yes & $9.83 \pm 5.53$ \\
\hline No & $4.28 \pm 2.85$ \\
\hline P-value & $0.000 *$ \\
\hline
\end{tabular}

(*) statistically significant $(p<0.05)$ 
Table (6): Relationship between nurses performance score regarding shift report handover and personal characteristics

\begin{tabular}{|c|c|}
\hline \multirow{2}{*}{ personal characteristics } & \multirow{2}{*}{$\begin{array}{c}\text { Performance score } \\
\text { Mean } \pm \text { SD }\end{array}$} \\
\hline & \\
\hline \multicolumn{2}{|l|}{ Age: (years) } \\
\hline$<25$ & $7.41 \pm 6.14$ \\
\hline$\geq 25$ & $17.64 \pm 8.13$ \\
\hline P-value & $0.000 *$ \\
\hline \multicolumn{2}{|l|}{ Gender } \\
\hline Male & $13.20 \pm 9.31$ \\
\hline Female & $9.50 \pm 7.79$ \\
\hline P-value & 0.331 \\
\hline \multicolumn{2}{|l|}{ Educational qualification } \\
\hline Bachelor of Nursing & $23.33 \pm 5.89$ \\
\hline Technical Health Institute & $7.85 \pm 5.96$ \\
\hline P-value & $0.000 *$ \\
\hline \multicolumn{2}{|l|}{ Years of experience } \\
\hline $1-2$ & $7.44 \pm 6.29$ \\
\hline 3 or more & $16.00 \pm 8.50$ \\
\hline P-value & $0.001 *$ \\
\hline \multicolumn{2}{|l|}{ Marital status } \\
\hline Single & $11.42 \pm 8.21$ \\
\hline Married & $6.57 \pm 6.33$ \\
\hline P-value & 0.057 \\
\hline \multicolumn{2}{|l|}{ Attending training courses } \\
\hline Yes & $21.83 \pm 9.77$ \\
\hline No & $8.08 \pm 5.87$ \\
\hline P-value & $0.000 *$ \\
\hline
\end{tabular}

(*) statistically significant $(p<0.05)$

Table (1): Demonstrates that the majority of the staff nurses' are aged less than twenty five years, females, have less than five years of experience $(75.6 \%, 88.9 \%$, $71.1 \%$ ) respectively. The majority of the studied staff nurses have a technical Health Institute Diploma (Nursing branch), and not attending any training programs $(86.7 \%$ \& $86.7 \%)$ respectively, as well as two thirds of the studied staff nurses are single $(68.9 \%)$.

Table (2): Displays that staff nurses' knowledge regarding shift report handover is generally low in all items especially in (types of nursing report about patients care in the department, the procedures established during the shift hand over, definition of report, the person in charge of communicating the shift's handover to the next shift and the Persons who involved in shift handover exchange $(11.1 \%, 13.3 \%$ \& $15.6 \%)$ respectively.

Table (3): Shows that the highest mean score was (2.93 \pm 1.74 ) for Knowledge about reporting with total mean score of staff nurses knowledge is very low (5.02 \pm 3.76).

Table (4): Demonstrates that the highest mean score was $(6.00 \pm 5.79)$ for Exchange contents of shift report with total mean score of staff nurses performance is low $(9.91 \pm 7.94)$.

Table (5): Reveals that there are statistical significant correlations between staff nurses' knowledge score regarding shift report handover and personal characteristics: Age $\left(\mathrm{p}=0.000^{*}\right)$, educational qualification $(p=0.000 *)$, years of experience $(p=$ $\left.0.004^{*}\right)$ and attending training courses $\left(\mathrm{p}=0.000^{*}\right)$.

Table (6): Shows that there are statistical significant correlations between staff nurses performance score regarding shift report handover and personal characteristics: Age $(\mathrm{p}=0.001 *)$, educational qualification $(\mathrm{p}=0.000 *)$, years of experience $(\mathrm{p}=$ $\left.0.001^{*}\right)$ and attending training courses $\left(\mathrm{p}=0.000^{*}\right)$.

\section{Discussion}

As regard studied staff nurses' knowledge about communication, the present study revealed that the studied staff nurses had deficient knowledge in communication process which includes; definition, characteristics of effective communication, principles, goals, etc. This congruent with Elsayed, (2013) who reported that the majority of nurses had low level of 
knowledge in communication related to communication skills. On the same line Azaze, Mohamed \& Taiee (2010) found that there was no statistical significant difference regarding to knowledge about communication process.

According to the Joint Commission on Accreditation of Health Organization (2014) many adverse effects and sentinel events that occur in the health care setting can be avoided when health care professionals employ good communication techniques. Many sentinel events are the direct result of poor communication among provider-to-provider and provider-to-family members.

As regard studied staff nurses' knowledge about shift report handover, the present study revealed that all staff nurses' have low knowledge about shift report handover ( definition of report, criteria for good report, goal of the shift handover, introductory information of shift handover, etc). This congruent with Khalaf, (2015) who stated that the nurses had deficient knowledge of shift report. This was noticed in most of the knowledge areas tested. Also, in the same line Elsayed, (2013) reported that the majority of nurses not aware of concept of shift report.

Stewart \& Hand, (2017) \& Bigani, \& Correia, (2018) emphasis that the nurse-nurse handover is recognized among nurses as a significant in maintaining continuity of care and when done poorly may have substantial safety issues. The goal of a bedside report is to improve the continuity of care, support the exchange of relevant patient information, and promote patient safety.

Moreover, staff nurses' knowledge about the process of exchanging of shift report handover the current study findings shows that all staff nurses' knowledge were very deficient about the process of exchanging shift report handover which includes; the person who write shift's handover, the place of writing shift's handover, Time of shift handover affairs the criteria required for the place of exchanging the shift handover, etc. These results were in agreement with Khalaf, (2015) who clarified that very few of staff nurses had satisfactory total knowledge of shift report. The deficiencies were particularly evident regarding the aim, elements, and characteristics of shift report, and of its introductory information.

Regarding observation of performance of studied staff nurses' about preparation pre-report handover, the present study revealed that majority of studied staff nurses had inadequate performance in items which include (writing shift's report, reviewing the contents of the report for each patient, ensuring that the information for each patient is complete, etc). This result agreed with Abdel All, (2016) who found that, all nurses had inadequate performance about writing shift's report and preparing all patients files and placing it in the hand-over place. On the same line Khalaf, (2015) clarified that the staff nurses' performance of shift report was deficient.
According to Anderson, Malone, Shanahan \& Manning, (2015) shift report is vital because it includes the passing of accountability and responsibility to the oncoming nurse. During this time the quality and safety of patient care may be compromised therefore it is imperative that nurses realize the importance of a detailed and consistent shift-to-shift report.

The current study result revealed that performance of staff nurses' about criteria of handover process were generally low at all items which include; conduct oral shift report at time, face to face interaction, answer the questions to the oncoming nurse if needed use understandable words, etc. This result is congruent with Khalaf, (2015) who clarified that the staff nurses' performance of shift report was deficient. On the same line Elsayed, (2013) found that handover process was generally very low the majority of studied nurses did not conduct oral report at time.

According to Riesenberg, (2012) who found that the value of face to face patient's handover offering the chance and the ability to ask questions between the sender and the receiver. While Safety et al., (2017) indicated that the three most important features of effective handover are two way face to face communication, written support tools and content in handover that captures the attention.

The study shows that majority of studied staff nurses not exchange the contents of report at patient's bedside. This result is congruent with (Shazly, 2003, Elsayed, 2013 \& Abdel All, 2016) who clarified that majority of staff nurses not exchange the shift report contents at patient bed.

Cairns, et al., (2013) emphasized that when report is given at the bedside by nurses, patients have a greater opportunity to participate in plan of care. Active participation from patients and families during bedside report reduces errors in communication. Patients can ask questions, feel involved, and have a sense their voice is being heard. When nurses are distracted and patient care questions go unanswered, these interruptions could result in unintentional patient harm. Moreover, Wakefield, Ragan, Brandt, \& Tregnago (2012), emphasized that the bedside allows patients and family involvement, increases teamwork among nurses, boosts accountability and improves effective communication between nurses and patients. Using the bedside handover ensures a standardized reporting process that allows the inclusion of all the critical information in a patient's plan of care to be addressed and conveyed to the nurse coming on duty.

The present study revealed that the highest total knowledge mean scores among nurses who had aged more than 25 years, female nurses had higher mean scores of total knowledge than male nurses. Also a higher mean score of total knowledge among nurses with bachelor degree and years of experience 3 or more. 
Moreover, the present study revealed that, there were higher mean scores of total knowledge among nurses who attend training courses in nursing documentation and were single. As well as the present study revealed that there were statistical significant correlation between staff nurses knowledge score regarding shift report handover and personal characteristics which include : Age, educational qualification, years of experience and attending training courses.

This result in agreement with Abdel All, (2016) who found that there were no statistical significant relation between total nurses' knowledge regarding shift report handover and personal characteristics. On the same line El- Gawab, (2013) who found that a limited number of nurses were attended training programs about documentation.

The present study revealed that Correlation between studied staff nurses' knowledge and their performance regarding shift report handover. There are significantly positive correlation. This finding is disagreed with (Seleim, 2012, Abd El-Kader, 2014 \& Abdel All, 2016) who found that, there was no significant correlation between nurses' knowledge and their performance.

The present study revealed that the highest total performance mean scores among nurses who had aged more than 25 years, male nurses' had higher mean scores of total performance than female nurses. Also higher mean scores of total performance among nurses with bachelor degree and years of experience 3 or more. Moreover, the present study revealed that, there were a higher mean score of total performance among nurses who attend training courses in nursing documentation and were single. As well as the present study revealed that there were statistical significant correlation between staff nurses' performance score regarding shift report handover and personal characteristics which include: Age, educational qualification, years of experience, and attending training courses.

This result in agreement with Abd El-Kader, (2014) \& Abdel All, (2016) who stated that there were no statistical significant relations between total nurses' performance and nurses' personal characteristics.

From the point of view of the researcher this result may be due to didn't the custom do to shift report handover as a part of routine work and they not attending program about importance of inter shift report.

\section{Conclusions}

In the light of the study results, the following conclusions can be drawn:

The staff nurses' in the study setting have deficient knowledge and inadequate performance of communication and shift report handover. There is a significant positive correlation between nurses' knowledge and their performance scores.

\section{Recommendations}

In view of the main study findings, the following recommendations are proposed.

- Creating strategies by Hospital decision makers to improve quality of shift handover.

- The applicability of shift report handover should be supported from the hospitals administration.

- Developing an electronic information system for the nursing documentation and enhancing its' implementation.

- Replication of the study at different health care settings.

- Regular staff development activities to update nurses' knowledge, skills and abilities and providing guidance and feedback related to documentation.

\section{References}

- Abdel_Aal, S., (2016): patient safety: Assessing nursing performance During shift handover, Unpublished Master Degree Thesis, Faculty of nursing Ain-Shams University. Pp.70-74.

- Anderson, J., Malone, L., Shanahan, K., \& Manning, J., (2015): Nursing bedside clinical handover - an integrated review of issues and tools. Journal of Clinical Nursing, 24(5/6), 662-671. doi:10.1111/jocn.12706

- Abd Elkader, H., (2014): Factors affecting nurses' performance regarding documentation in general surgical units. , Master Degree, Faculty of nursing, Ain Shams University. pp. $100-114$.

- Agency for Healthcare Research and Quality, (2012): Patient Safety and Quality: An Evidencedbased Practice Handbook for Nurses. Retrieved October 2, 2013 from http://www.ahrq. gov/ qual/ nurseshdbk/

- Azize, E., Mohamed, \& Taie, E., (2010): Developing and validating a manual for documenting patient care, 1 (1)pp.77.

- Barbara, L., \& Lynne, R., (2018): Fundamentals of nursing active learning for collaborative practice, Communication, 2th ed. Elsevier Health Sciences, Ch, 3, p36-39

- Bigani, D., \& Correia, A., (2018): On the same page: Nurse, patients, and family perceptions of change-of-shift bedside report. Journal of Pediatric Nursing, 41, 84-89. doi: 10.1016/jpedn.2018.008.

- Collins, B., Couture, M., Kang, P., (2018): Quantifying and Visualizing Nursing Flowsheet Documentation Burden in Acute and Critical Care.Journal list, AMIA. Annual Symposium proceeding. Archive, Pp. 348- 357

- Cairns, L., Dudjak, L., Hoffman, R., \& Lorenz, H., (2013): Utilizing bedside shift report to improve the effectiveness of shift handoff. Journal of 
Nursing Administration, 43(3), 160-165. Doi:10.1097/NNA.0b013e318283dc02.

- Elsayed, S., (2013): The effect of implementing SBAR shift report on quality of reporting of patient care. Doctorate Degree, Faculty of nursing, Ain Shams University .pp. 114-117.

- El-Gawab F., (2013): Quality of nursing documentation in intensive care units in selected Hospitals, faculty of nursing, Port Said University, pp.139-141.

- Khalaf, D., (2015): Evaluative Feedback Related to Intradepartmental Communication among Nurses: Reflections on Nurses' and Patients' ssEmpowerment. Doctorate Degree Thesis, Faculty of nursing, Ain Shams University .Pp. 14-15.

- Kelley, T., Brandon, D., \& Docherty, S., (2014): Electronic Nursing Documentation as Strategy to improve quality of patient care. Vol. 43, No (2), Pp. 154-162.

- Potter, P., Perry, A., Stockert, P., \& Hall, A., (2017): Fundamentals of Nursing, 8th ed, Elsevier Mosby.Canada, Unit.4, Pp. 349- 357.

- Riesenberg, L., (2012): Shift-to-Shift Handoff Research: Where Do We Go From Here? Journal of graduate medical education, 4(1), pp.48.Availableat:

http://www.pubmedcentral.nih.gov/articlerender.fcg i? artid $=3312531 \&$ tool $=$ pmcentr

ez\&rendertype $=$ abstract.

- Stewart, K., Hand, K., (2017): SBAR, Communication, and patient safety: An integrated literature review. Medsurg Nursing, 26 (5), 297305.

- Seleim, M., (2012): Nurses compliance with patient safety standards at Intensive care units in Nasser Institute Hospital, Master Degree, Faculty of nursing, Ain Shams University. pp. 122-126.

- Safety, P., Columbia, B., \& Thinking, S., (2017): Human Factors in Clinical Shift Handover Communication Review of reliability and resilience principles applied to Change of Shift Report. Canadian Journal of Respiratory Therapy, 15; 17(1):213.

- Shazely, M., (2003): Developing intradepartmental nursing reporting system El-Demerdash University Hospital, Doctorate thesis, Faculty of Nursing AinShams University. pp. 112-114.

- The Joint Commission (2016): National Patient Safety Goals presentation. Retrieved from http://www.jointcommission. org/npsg_presentation

- The Joint Commission (2014): Improving transitions of care: Handoff communications. Retrieved from http://www.centerfortransforminghealth care.org/assets/4/6/ handoff_comm_storyboard.pdf.
- The Joint Commission on Accreditation of Health Organization, (2012): Joint commission center for transforming healthcare releases targeted solutions tool for hand-off communications. Joint Commission Perspectives, 32(8).

- Wakefield, D., Ragan. R., Brandt, J., \& Tregnago, M., (2012): Coordination of care: Making the transition to nursing bedside shift reports. The Joint Commission Journal on Quality and Patient Safety, 38(6), 243-253.

- Winifred, N., (2017): Nurse-To-Nurse End of Shift Report. Degree of Doctor of Nursing Practice, Facalty of Nursing, Walden University, P.1

- Wikstrom, B., \& Svidén G., (2014): Exploring communication skills training in Undergraduate nurse education by means of a curriculum. Nursing Reports; 26(1):65-7 